\title{
Women Entrepreneurship In Developed And Emerging Market: Evidence From The Literature In Multidimensional Way
}

\author{
Saima Tabassum Siddiqui \\ Asif Hussain Samo \\ \& \\ Kainat Meraj \\ Department of Business Administration \\ Sindh Madressatul Islam University
}

\begin{abstract}
The concept of entrepreneurship is widely studied and acknowledged. Over the past three decades, scholarly interest in the field of women entrepreneurship has been expanded. The phenomena of women entrepreneurship are moving towards being more specific for researcher. The purpose of this study is to collate and present a detailed analysis of literature on women entrepreneurs. The paper uses qualitative methodology that is systematic literature review SLR approach in order to critically determine and explore women entrepreneurs for both emerging and developed market from January 2009 to December 2018 based on five dimensions, i.e. challenges, skills, stereotypes, motivations, and financial stability. This review paper concentrates on studies published in master journal list. The study summarizes the findings of 73 articles out of these all articles, 36 articles were on emerging market and remaining 37 articles were on developed market. Findings of the study suggest that women in developing countries should focus more on consistency in their efforts when they embark on the journey of business, as the challenges and stereotypes are usually manageable. The study provides comparative overview of women entrepreneurship. It brings together coherent research literature on women entrepreneurship from multiple dimensions and thus creates a concise body to knowledge.
\end{abstract}

Keywords: Women Entrepreneurship, Emerging Market, Developed Market, Challenges.

\section{تلخيص}

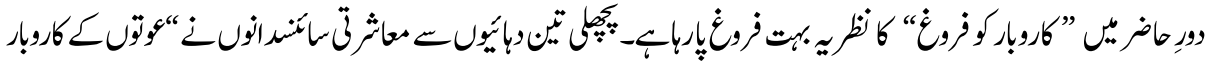

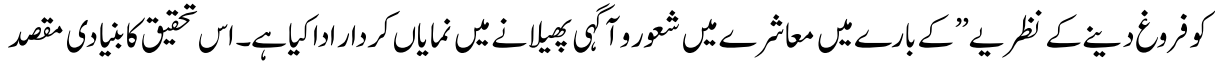

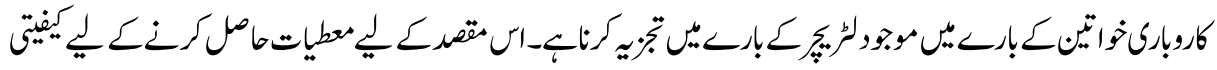

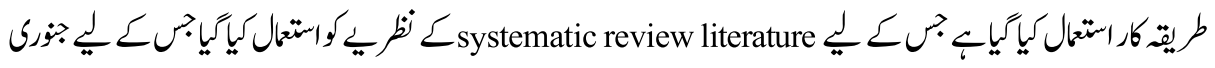

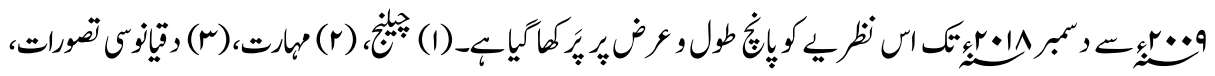

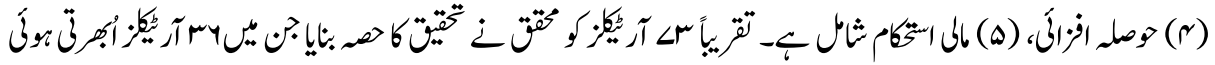




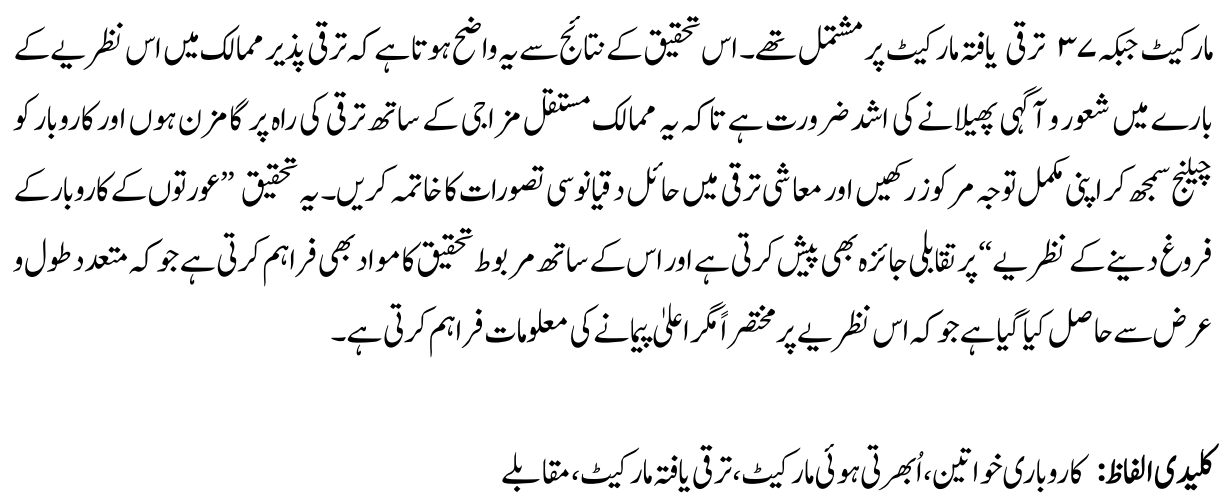

\section{Introduction}

An entrepreneur is a term which is related with initiating a business, According to the Jean Baptiste in the $19^{\text {th }}$ century, "Economic resources can be shift through an entrepreneur into the arena of lower productivity or the greater yield" (Dees, 1998). In general, entrepreneurship is an activity of evaluating the new business strategy, which contains a high level of uncertainty and accountability (Ibeh, 2009). The level of risk an entrepreneur takes while initiating the business idea paybacks in the form of monetary rewards (Sharma, 2013). Entrepreneurship is considered in both emerging and developed markets as an informal sector and common in all around the world (Ibeh, 2009).The phenomenon of entrepreneurship individually and the phenomenon of women entrepreneurship collectively play a significant role in the economic development of the country and in terms of poverty reduction as well (Coleman \& Kofi, 2008; Iganiga, 2008; Stephen \& Wilton, 2006; William \& Thawatchai, 2008). In all societies, the government is required to create a favorable atmosphere where financial, socio-cultural, economic and other facilities are provided to an entrepreneur to explore their idea (Ekpe, 2015).

The concept of entrepreneurship is widely studied and acknowledged. The preceding research in this context explains that it plays a significant role in the economic arena of the country, but still, our focus on the connection between economic development and entrepreneurship is not properly addressed" (Sarfaraz, Faghih, \& Majd, 2014). When it comes to gender-wise entrepreneurship, it is generally considered that women have weak entrepreneurial intentions than men (de Bruin, Brush, \& Welter, 2007; DíazGarcía \& Jiménez-Moreno, 2010; Gupta, Turban, Wasti, \& Sidkar, 2009). Another perception is that entrepreneurial intentions and attitudes transform into different cultural contexts (Shinnar, Giacomin, \& Janssen, 2012). The term "Women entrepreneur" referred to the women who are the risk taker and manages \& organizes an enterprise (Sharma, 2013). 
Researchers tend to explore the motivations of women to become entrepreneurs (Senik \& Jani, 2012). There is noticeable growth for last few years in women entrepreneurs; in fact, in comparison with male business ventures women ratio is higher in some societies (Senik \& Jani, 2012). Generally, there is a common stereotype that since men dominate the arena of entrepreneurship suffices to believe that men are, by virtue of their gender, more towards initiating new business and in better way (Brush 1992; Berg 1997). Evidence from previous studies shows that most successful firms are initiated by motivated men (Cooper and Gascon 1992). Moreover, if we go a decade back, we find a few numbers of researches on women entrepreneurs and gender-wise entrepreneurship (Brush \& Vanderwerf, 1992; Kobeissi, 2010).

Monetary advantages are not the prime source of motivation for a good entrepreneur for both males and females. They have different desires to be entrepreneurs; some of the considerations include a desire for freedom, creativity, and self-actualization (Itani, Sidani, \& Baalbaki, 2011). In developed countries, women entrepreneurs enjoy more equal rights and opportunities than in emerging markets, and it is measured in terms of increased income per capita (Dollar, Gatti, \& Filmer, 1999; Sarfaraz et al., 2014). The concept of women entrepreneurship has been studied in multidimensional ways, such as challenges women entrepreneurs face (lack of capital, lack of guidance, gender discrimination, societal issues, and many more) (Mwobobia, 2012). Financial stability problems, what type of skills they have and what type of stereotypical beliefs are there for them. The aim of this research is to conduct a systematic review of literature and explore the phenomenon of women entrepreneurs in five dimensions (Challenges, Skills, Stereotypes, motivations and financial stability) for both emerging market and developed market".

\section{Objectives of the Study}

- To explore the differences in the phenomena of women between developed markets and emerging markets in the context of the challenges they face.

- To find out the differences in the phenomena of women, entrepreneurs between developed market and emerging market in the context of skills they have.

- To explore the differences in the phenomena of women entrepreneurs between developed markets and emerging markets in the context of stereotypes.

- To determine the differences in the phenomena of women entrepreneurs between developed markets and emerging markets in the context of motivation.

- To explore the differences in the phenomena of women entrepreneurs between developed markets and emerging markets in the context of financial stability. 


\section{Methodology}

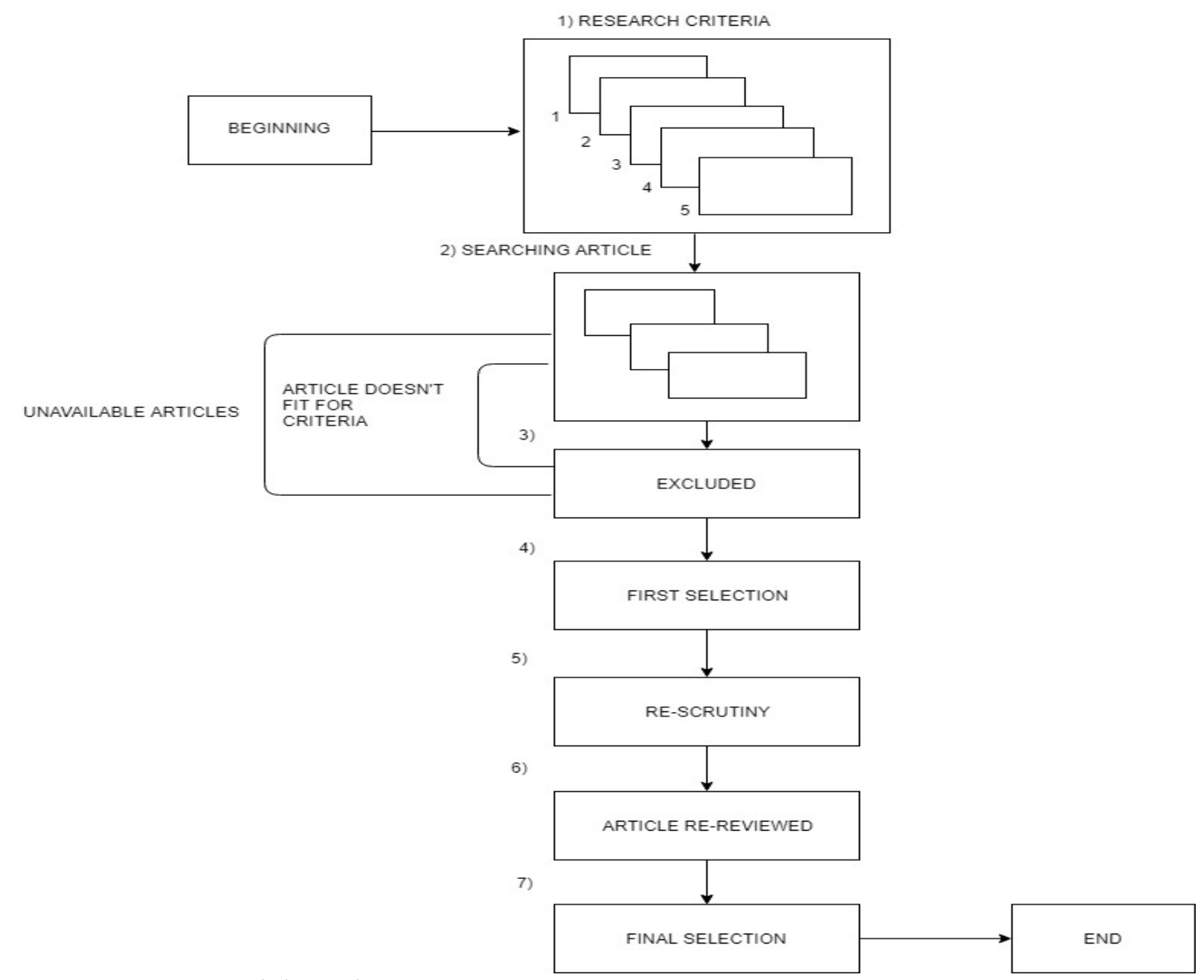

Source: Data set elaboration

The method of a systematic review of the literature is appropriate for the current study because this method aims to construct a scientific summary through the references in a separate phenomenon of knowledge (Popay et al., 2014). Some basic principles are used to fulfill its purpose, which is highlighted by Thorpe, Holt, Macpherson and Pittaway, (2005), such as clarity, equality, accessibility, synthesis, transparency which helps research prospects in terms of replicability (Jones, Coviello, \& Tang, 2011). The systematic review of the current study is designed regarding the women entrepreneurship literature to develop an understanding regarding the phenomena of women entrepreneur for developed and emerging markets. The aim of this research is to highlight the work on this phenomenon. To do so, systematic review research is the most appropriate way to conduct the study, and for the purpose, the flow chart is created by using Smart Draw, which shows the process of this systematic review clearly. It can be seen in Figure 1. 


\section{Selection Criteria and the First Evidence}

The researches on female entrepreneurship, which has been done previously on the basis of a systematic literature review followed different selection criteria of studies. In this study, we chose the traditional method of review study which is shown in fig 1 clearly. These criteria are established on the basis of three restrictions, and they are the following:

- The studies which are published in the master journals were considered to maintain a high level of quality \& standard. Therefore, conference proceedings, unpublished work, chapters in books, books were not included.

- The language of research studies selected for the review paper must be written in English.

- $\quad$ Research papers published from January 2009- December 2018 were included.

After ensuring the above criteria, Articles were selected by using electronic databases. Different electronic databases used for searching the articles included EBSCO, Econlit \& Google scholar (Aliaga-Isla, \& Rialp, 2013). Keywords used for selection of articles comprised of "women" or "Female" or "gender" in their abstract. Finally, substantive relevance of the managerial profile of each selected article was ensured, provided that each selected article should at least contain one of the following additional keywords, i.e. "corporation" or "company" or "entrepreneur' or "own" or "business" or "corporation" or "venture" (De Vita, Mari, \& Poggesi, 2014). As the idea behind this research paper was to systematize empirical \& theoretical findings of prior work based on various dimensions of women entrepreneurs that are motivation, challenges, stereotypes, skills, and financial stability, strict Inclusion and exclusion criteria were designed. For inclusion criteria, (a) Empirical and non-empirical studies were included in order to capture empirical findings. (b) Theoretical articles cover assumptions used in research, thereby theoretical articles were added. (c) To ensure the cross country and cross-sector comparison, articles of developed \& emerging markets and articles of different sectors were taken in to account for further analysis. Additionally, for Exclusion criteria, (a) research articles that were used by previous researchers were excluded, i.e. articles published before 2009. (b) Articles published other than master journal list were excluded. (c) Prospect female entrepreneurs and attitude of female students towards entrepreneurship were also not discussed in this study.

According to one specific criterion of developed and emerging markets for inclusion and exclusion, 73 articles were finalized from 112 articles. Specifically, studies on women entrepreneurs in developed and emerging markets were included in data set. The final 
sample for analysis resulted in 73 research studies that were further categorized in following manner:

- The distribution of articles according to the publication

- The distribution of articles according to the selected time frame

- The distribution of articles between the emerging and developed markets.

- The distribution of articles in different dimensions of each market.

The distribution of articles as per the above requirements is presented in Table. 1, categorizing the articles on emerging markets by journal name, year of publication, methodology, and frequency of papers published in a particular journal (Popay et al., 2014).

Table - 1

List of journals of emerging market articles used for the systematic methodology

\begin{tabular}{|c|l|c|c|c|}
\hline $\mathbf{N}$ & Journal Name & $\begin{array}{c}\text { No of Papers } \\
\text { Published }\end{array}$ & Year & $\begin{array}{c}\text { Empirical-Non- } \\
\text { Empirical }\end{array}$ \\
\hline 1. & Gender, Work and Organization. & 2 & 2009,2013 & $\begin{array}{c}\text { Qualitative, } \\
\text { Quantitative }\end{array}$ \\
\hline 2. & Int Adv Econ Res & 1 & 2010 & Quantitative \\
\hline 3. & Human Relations & 1 & 2009 & Qualitative \\
\hline 4. & Journal of East-West Business, & 1 & 2009 & Quantitative \\
\hline 5. & Social and Behavioral Sciences & 1 & 2013 & Qualitative \\
\hline 6. & $\begin{array}{l}\text { Equality Diversity and Inclusion: An } \\
\text { International Journal }\end{array}$ & 1 & 2011 & Qualitative \\
\hline 7. & Vulnerable Groups \& Inclusion & 1 & 2012 & Qualitative \\
\hline 8. & $\begin{array}{l}\text { Journal of International Women's } \\
\text { Studies }\end{array}$ & 1 & 2011 & Quantitative \\
\hline 9. & EUROPE-ASIA STUDIES & 1 & 2011 & Qualitative \\
\hline 10. & $\begin{array}{l}\text { International Journal of Business } \\
\text { and Social Science }\end{array}$ & 1 & 2011 & Quantitative \\
\hline 11. & Work and Occupations & 1 & 2009 & Quantitative \\
\hline 12. & $\begin{array}{l}\text { Journal of Small Business and } \\
\text { Enterprise Development }\end{array}$ & 3 & 2016,2012, & $\begin{array}{c}\text { Qualitative } \\
\text { Quantitative }\end{array}$ \\
\hline 13. & International Journal of Gender and & 3 & 2009,2011, & Quantitative \\
Entrepreneurship & 2013 & \\
\hline 14. & international small business journal & 1 & 2009 & Quantitative \\
\hline 15. & Small Bus Econ & 2 & 2009,2011 & $\begin{array}{l}\text { Qualitative, } \\
\text { Quantitative }\end{array}$ \\
\hline
\end{tabular}




\begin{tabular}{|c|c|c|c|c|}
\hline 16. & $\begin{array}{l}\text { European Journal of Development } \\
\text { Research }\end{array}$ & 1 & 2010 & Qualitative \\
\hline 17. & $\begin{array}{l}\text { A Publication of the National Civic } \\
\text { League }\end{array}$ & 1 & 2011 & Quantitative \\
\hline 18. & $\begin{array}{l}\text { Journal of Small Business } \\
\text { Management }\end{array}$ & 4 & $\begin{array}{l}2009,2011 \\
2011,2014\end{array}$ & $\begin{array}{l}\text { Qualitative, } \\
\text { Quantitative }\end{array}$ \\
\hline 19. & $\begin{array}{l}\text { International Journal of } \\
\text { Entrepreneurial Behavior \& Research }\end{array}$ & 2 & 2011,2013 & $\begin{array}{l}\text { Qualitative, } \\
\text { Quantitative }\end{array}$ \\
\hline 20. & Baylor university & 1 & 2013 & Qualitative \\
\hline 21. & Small Bus Econ & 1 & 2011 & Qualitative \\
\hline 22. & $\begin{array}{l}\text { Women's Empowerment and } \\
\text { Economic Development }\end{array}$ & 1 & 2011 & Qualitative \\
\hline 23. & Institute of Labor Economics & 1 & 2009 & Quantitative \\
\hline 24. & Journal of Business Venturing & 1 & 2015 & Qualitative \\
\hline 25. & Federal Reserve Bank of New York & 1 & 2009 & Quantitative \\
\hline \multirow[t]{2}{*}{26.} & J Int Entrep & 1 & 2010 & Qualitative \\
\hline & & 36 & & \\
\hline
\end{tabular}

Source: Data set elaboration

From 73 articles, 36 articles were based on women entrepreneurship in the emerging market and out of these 36 articles, 14 articles used quantitative techniques \& remaining 24 used qualitative techniques, thus uncovering the fact that scholars prefer to use life stories of women entrepreneurs to describe the phenomenal characteristics of entrepreneur (Essers, Benschop \& Doorewaard 2010). Overall, five main dimensions were included to meet the objectives of the research to understand the phenomenon of women entrepreneurship. These dimensions were motivation, challenges, skills, stereotypes, and financial stability. Likewise, Table 2 represents the segregation of articles on developed markets by journal name, year of paper published and methodological techniques. Interestingly out of 37 articles, 16 articles followed qualitative technique and rest followed quantitative techniques reflecting that research for developed market on entrepreneur phenomenon prefers to use empirical investigations to understand relationship of dependent and independent variable along with some interactions that have been used as proxy for entrepreneurship (Vinogradov and Kolvereid, 2010). 
Table - 2

List of journals of developed market articles used for the systematic methodology

\begin{tabular}{|c|c|c|c|c|}
\hline $\mathbf{N}$ & Journal name & $\begin{array}{c}\text { No of papers } \\
\text { published }\end{array}$ & Year & \begin{tabular}{|c} 
Empirical- \\
non-empirical
\end{tabular} \\
\hline 1. & Gender, Work and Organization. & 2 & 2009,2013 & $\begin{array}{l}\text { qualitative, } \\
\text { quantitative }\end{array}$ \\
\hline 2. & Int Adv Econ Res & 1 & 2010 & quantitative \\
\hline 3. & Human Relations & 1 & 2009 & Qualitative \\
\hline 4. & Journal of East-West Business, & 1 & 2009 & quantitative \\
\hline 5. & Social and Behavioral Sciences & 1 & 2013 & Qualitative \\
\hline 6. & $\begin{array}{l}\text { Equality Diversity and Inclusion:An } \\
\text { International Journal }\end{array}$ & 1 & 2011 & Qualitative \\
\hline 7. & Vulnerable Groups \& Inclusion & 1 & 2012 & Qualitative \\
\hline 8. & $\begin{array}{l}\text { Journal of International Women's } \\
\text { Studies }\end{array}$ & 1 & 2011 & quantitative \\
\hline 9. & EUROPE-ASIA STUDIES & 1 & 2011 & Qualitative \\
\hline 10. & $\begin{array}{l}\text { International Journal of Business and } \\
\text { Social Science }\end{array}$ & 1 & 2011 & Quantitative \\
\hline 11. & Work and Occupations & 1 & 2009 & Quantitative \\
\hline 12. & $\begin{array}{l}\text { Journal of Small Business and } \\
\text { Enterprise Development }\end{array}$ & 3 & $\begin{array}{l}2016,2012, \\
2013\end{array}$ & $\begin{array}{l}\text { qualitative, } \\
\text { quantitative }\end{array}$ \\
\hline 13. & $\begin{array}{l}\text { International Journal of Gender and } \\
\text { Entrepreneurship }\end{array}$ & 3 & $\begin{array}{l}2009,2011, \\
2013\end{array}$ & Quantitative \\
\hline 14. & International small business journal & 1 & 2009 & Quantitative \\
\hline 15. & Small Bus Econ & 2 & 2009,2011 & $\begin{array}{l}\text { qualitative, } \\
\text { quantitative }\end{array}$ \\
\hline 16. & $\begin{array}{l}\text { European Journal of Development } \\
\text { Research }\end{array}$ & 1 & 2010 & Qualitative \\
\hline 17. & $\begin{array}{l}\text { A Publication of the National Civic } \\
\text { League }\end{array}$ & 1 & 2011 & Quantitative \\
\hline 18. & $\begin{array}{l}\text { Journal of Small Business } \\
\text { Management }\end{array}$ & 4 & $\begin{array}{l}2009,2011, \\
2011,2014\end{array}$ & $\begin{array}{l}\text { qualitative, } \\
\text { quantitative }\end{array}$ \\
\hline 19. & $\begin{array}{l}\text { International Journal of } \\
\text { Entrepreneurial Behavior \& Research }\end{array}$ & 2 & 2011,2013 & $\begin{array}{l}\text { qualitative, } \\
\text { quantitative }\end{array}$ \\
\hline 20. & Baylor university & 1 & 2013 & Qualitative \\
\hline 21. & Small Bus Econ & 1 & 2011 & Qualitative \\
\hline 22. & $\begin{array}{l}\text { Women's Empowerment and } \\
\text { Economic Development }\end{array}$ & 1 & 2011 & Qualitative \\
\hline 23. & Institute of Labor Economics & 1 & 2009 & Quantitative \\
\hline 24. & Journal of Business Venturing & 1 & 2015 & Qualitative \\
\hline
\end{tabular}




\begin{tabular}{|c|l|c|c|c|}
\hline 25. & Federal Reserve Bank of New York & 1 & 2009 & Quantitative \\
\hline 26. & J Int Entrep & 1 & 2010 & Qualitative \\
\hline & & Sum & $\mathbf{3 7}$ & \\
\hline
\end{tabular}

Source: Data set elaboration

\section{Findings of the systematization}

This section provides an in-depth analysis of 73 articles for understanding various dimensions of women entrepreneurship used by previous researchers. The consistency of these dimensions is shown in Table 3, indicating five main dimensions mostly used in prior literature for emerging and developed markets, i.e. Motivation, Challenges, Skills, Stereotype, and Financial stability.

\section{Table -3}

List of articles by dimensions

\begin{tabular}{|l|c|c|}
\hline Clusters & Sub clusters & No. of papers \\
\hline $\begin{array}{l}\text { Women entrepreneur in } \\
\text { emerging market }\end{array}$ & Motivation & 11 \\
\hline & Challenges & 10 \\
\hline & Stereotypes & 2 \\
\hline & Skills & 9 \\
\hline $\begin{array}{l}\text { Women entrepreneur in } \\
\text { Developed market }\end{array}$ & Financial stability & 4 \\
\hline & Motivation & 7 \\
\hline & Challenges & 6 \\
\hline & Stereotypes & 5 \\
\hline & Skills & 9 \\
\hline
\end{tabular}

Source: Data set elaboration

Particularly, the analysis has been done for two main clusters, i.e. emerging and developed markets. From the dataset, these two clusters are further segregated into five sub-clusters (motivation, challenges, Stereotypes, Skills, Financial Stability). Each of the dimensions shows female entrepreneurs in their unique way.

\section{Result and Discussion}

Figure 1 displays the themes and subthemes we have extracted from the systematic review of the articles. Women entrepreneurs in developed and emerging markets tend to differ when it comes to challenges, they face, stereotypes they encounter, skills they have, motivations they drive from, and financial stability problems they come across. 
Figure 1:

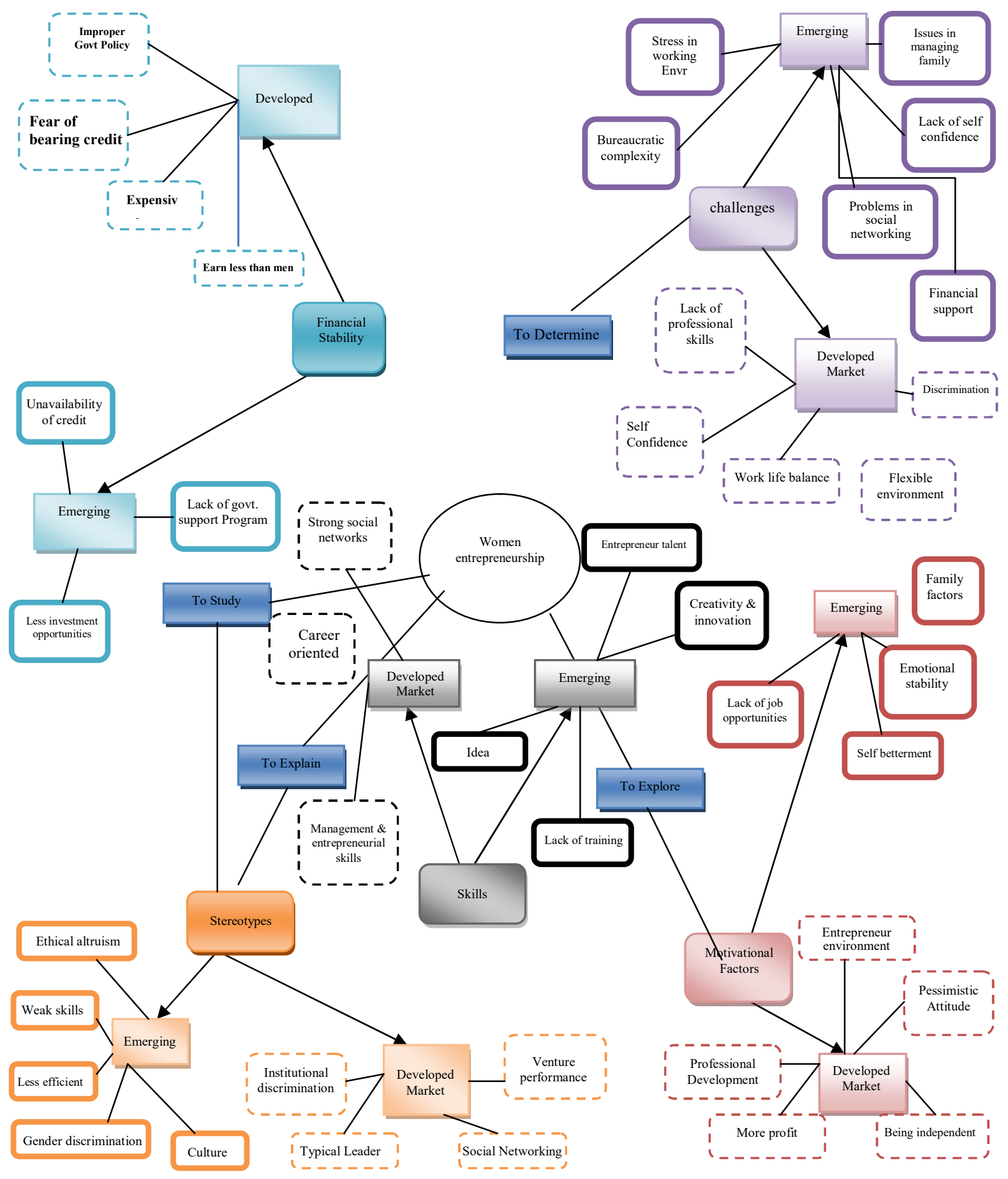




\section{Women Entrepreneurship}

\section{Motivation}

The most repeated factor which motivates women in developed countries is selfcommitment, being independent, self-fulfillment, self-achievement, identity recognition, flexible working environment, and being their own boss (Apergis \& Pekka-Economou, 2010; Lewis, 2013). These factors create inner satisfaction, which stimulates them to work smarter and harder. They don't need someone else to rely on. On the other hand, in emerging economies, family factors, self-betterment, public recognition, informative networks, financial independence, power of decision making, availability of investment, emotional stability along with self-fulfillment, self-commitment, being independent are used s drivers for motivation among women entrepreneur. To identify sub-dimensions of motivation, we came across with 7 research papers for developed markets and 11 research papers for the emerging market.

The second most repeated factor was self-enhancement that works for successful women entrepreneurs as motivation. Self-enhancement in such cases refers to gain knowledge, to acquire new skills, to have the best personality, to have the pessimistic attitude, to be able to decide their own future and to have the better professional development (Knorr, Garzón, \& Martínez, 2011). In transitional economies, most of the women love to have strong personal \& interpersonal skills. These skills help women to be successful entrepreneurs (Hossain, Naser, Zaman, \& Nuseibeh, 2009). The motivational reason is self-reliance in the sense that after becoming a good entrepreneur women have the feeling of achievement and being their own boss (Raman, Anantharaman\& Ramanathan, 2013).

Another commonly used factor which motivates women to be an entrepreneur is a family factor which includes low family income, the necessity to combine work, personal family reasons, to have a better lifestyle and the other family responsibilities (Itani et al., 2011). Most of the time females look for businesses to help their parents and to support their families, as every other person wants to have a better lifestyle and living standard. For developing countries, among all factors the most repeated factor for the motivation of women entrepreneurs includes an economic factor, i.e., money, to increase income or to maintain their lifestyle and, most importantly, financial independence (Alam, Jani, \& Omar, 2011;Sharma, 2013).

\section{Challenges}

In a developed market such as that of the US, female entrepreneurs are comparatively more ambitious about their professional identity than other countries. Attention in these countries towards the role model and learning from the external role models are 
preferred by these women (Singh, Vinnicombe, \& James, 2006). Women in developing countries, however, are ambitious too, but they face various challenges and difficulties as phenomena of entrepreneurship are somewhat new for the people of developing nations.

As shown in table 3, 6 research papers identified challenges as the relevant dimension for women entrepreneurs in the developed market. Major challenges faced by this entrepreneur are high degree of unbalance work-life, financial support, access to capital, and lack of networking (Al-sadi, 2011; Nordenmark, Vinberg, \& Strandh, 2012; Salmenniemi, Karhunen, \& Kosonen, 2011).In emerging economies, women face some major challenges, and they end up searching for financial loans (Parvin, Jinrong, \& Rahman, 2012; Ramadani, 2015). The major issues in both economies area high level of unbalanced work-life balance due to which most of the women quit entrepreneurship for the sake of their families (Emslie \& Hunt, 2009; Rehman \& Roomi, 2015). Moreover, in developed countries women come across the maledominant sector, have access to advanced technology, more opportunities and proper training whereas in developing countries women do not have proper governmental support programs, prejudice against women, faces injustice and the highest degree of restrictions due to religion and bureaucratic complexity (Drine \& Grach, 2010; Mathew \& Panchanatham, 2016).

\section{Skills}

Skill as a driving force for women entrepreneurship was found out in 18 research papers divided equally for both the markets (developed \& Emerging). According to previous studies, women entrepreneurs are more skilled than men, but due to the challenges that they face, women could not perform efficiently. For the developed countries women are considered to have strong social connections as it is easy them to make good connections with others in this fast-moving world. So, these females use their skills to run the business or grow it to the next level. Good business management, human resource, and entrepreneurial competencies, flexible nature, desire for independence, training awareness are some female personal skills that led her to the success (Ahmad, 2011; Coetzer, 2016; Danis, Clercq, \& Petricevic, 2011; Kirkwood, 2009).

Women entrepreneurs in emerging market as well are well managed, innovative, committed to their work/business, can manage stress and the prior business activities which gives the positive impact on the business (Al-dajani \& Marlow, 2010; Alam et al., 2011; Bardasi, Sabarwal, \& Terrell, 2011; Grine, Fares, \& Meguellati, 2015). However, the challenges they encounter hamper their progress substantially. 


\section{Stereotypes}

The foremost stereotype was found to be that there is an over-generalized belief about women entrepreneurs that women could not run the business better than men (Baron, Markman, \& Hirsa, 2001). From the last decade, women are passionate about entering the business field, but still, for the leadership positions men are preferred over women in most of the large business organizations (Orser, Riding, \& Manley, 2006).

These differences not only exist for the leadership positions but for the evaluation of business opportunities as well, as men and women perceive differently for entrepreneurial opportunities (Heilman \& Chen, 2003). It is indicated by empirical and non-empirical evidence that women often show less productivity than men in exploring entrepreneurial opportunities (Arenius \& De Clerk, 2005). It is compulsory for men and women both to do a favorable assessment of business opportunities, their attitude towards evaluation means a lot while starting a new business (Nicolaou, Shane, Cherkas, \& Spector, 2009). Subsequently, there is curiosity like how, why and when some people evaluate business opportunities negatively and some of them positively (Chiles, Bluedorn, \& Gupta, 2007).

Analysis of this attribute was done from 8 research papers, distributed with a ratio of 5:2 for the developed and emerging economy. Women are considered as typical leader, but there is a stereotypical belief as well about women that they tend to have less creativity and innovative skills (Kirkwood, 2009; Welsh, Memili, Kaciak, \& Ochi, 2014). The other stereotypes include that they cannot make a balance between family and work-life such that women businesses are portrayed as underperforming businesses compared to menowned businesses. In the larger sector women entrepreneur is less likely to participate in the startup of entrepreneurial activities (Estrin \& Mickiewicz, 2011; Mcgowan, Cooper, Durkin, \& O'Kane, 2015). As the good news is expected from the men entrepreneur than female-owned businesses, nevertheless one of the studies showed that women rate of reporting great opportunity is higher than men, which almost broke the stereotype made for females globally (Chiles et al., 2007). In emerging economies, women entrepreneurs are underrated before starting a business like by saying that it's a men's job women cannot be successful entrepreneurs (Piacentini, 2013; Ramadani, 2015). These types of demotivating stereotypes are only for women. The other stereotypes include weak skills in operations, marketing, planning, and finance; therefore women can only run in small scale businesses with little capital (Ramadani, 2015).

\section{Financial Stability}

Women entrepreneurs all over the world are mainly working to be financially stable and independent. Globally, in most of the nations, especially in developed countries, economies witness high-level of economic growth due to entrepreneurial startups such as 
Australia (Bennett \& Dann, 2000), New Zealand (McGregor \& Tweed, 2002), US (Carter \& Allen, 1997), and Canada (Mirchandani, 1999). One-third of all businesses run by females in the developed countries of the world (Wijdicks, Bamlet, Maramattom, Manno, \& McClelland, 2005). Female entrepreneurship is an encouraging trend as the statistics had shown an increase of 18.2 percent in the UK between the horizon of 2000 and 2008 (Peters, 2014).

In transition economies, female entrepreneurs trend is an encouraging one but one of the major issues which break their way of doing business is availability of finance, even if women obtain microfinance there are still a lot of hurdles present for females (Ekpe, 2010; Mahmood, Hussain, \& Matlay, 2014; Mansell, 2014).

The methodology of this research provides a broader review of the interdisciplinary study on women entrepreneurship in emerging and developed market in different dimensions includes motivation, challenges, skills, stereotypes, and financial stability published since 2009 to 2019, in order to examine what has been done and to draw the future research lines on female entrepreneurship. Based on the content analysis of previous studies, five key dimensions that are (motivation, financial stability, stereotypes, skills, and challenges) of women entrepreneur helps to analyze the phenomenon of female entrepreneurship in emerging and developed market. The challenges that women entrepreneurs face in both markets include the stereotypical beliefs which already exist in the mind of people to demotivate them (Hughes, Jennings, Brush, Carter, \& Welter, 2012).

\section{Conclusions}

The phenomena of women entrepreneurship are moving towards being more specific for researchers since the last decade. The methodology of this study follows a systematic review approach. Content analysis of 73 research articles on women entrepreneurship was done, and analysis revealed that in developed economies motivation factors include self-commitment, self-fulfillment, enhance personal skills and financial independence whereas in developing countries motivation factors for women entrepreneurs belong to training, availability of startup capital, source of employment and better lifestyle. As far as challenges are concerned, women face gender discrimination in both markets in terms of the high level of work-life unbalance, financial support, and access to capital, investment opportunities, lack of networking, and lack of market knowledge. Entrepreneurs of both the markets possess a lot of skills, but their skills are different, i.e. management of business, human resources, time management, compromising nature to tackle a task, interpersonal skills, and desire to be independent. However, Stereotypes and financial stability do not have much difference for both markets as stereotypes are based on gender discrimination. Financial stability factors are made on the basis of economic development and government policies. The findings of this research paper are helpful for 
policymakers and scholars for addressing future efforts on the phenomena of women entrepreneurs.

\section{Recommendations}

Conducting research on women entrepreneurship in developing economies is significant. This research explored the comparative analysis of factors regarding this phenomenon. It is recommended that women in developing countries should focus more on consistency in their efforts when they embark on the journey of business, as the challenges and stereotypes are usually manageable. The government should devise policies of consistent support in their financial sustainability, especially in their struggle period. Moreover, there should be a nationwide campaign against the stereotypes people have regarding working women and women entrepreneurs. We also recommend that future research should be conducted to test these dimensions and their empirical impact.

\section{References}

Ahmad, S. Z. (2011). Evidence of the Characteristics of Women Entrepreneurs in the Kingdom of Saudi Arabia An Empirical Investigation. https://oi.org/10.1108/ 17566261111140206

Al-dajani, H., \& Marlow, S. (2010). Small Business Journal. https://doi.org/10.1177/ 0266242610370392.

Aliaga-Isla, R. \& Rialp, A. (2013). Systematic Review of Immigrant Entrepreneurship Literature: Previous Findings and Ways Forward. Entrepreneurship \& Regional Development, vol.25:9-10, pp.819-844.

Al-sadi, R. (2011). Woman Entrepreneurship in the Al-Batinah Region of Oman : An Identification of the Barriers, vol.12:3, pp.58-75.

Alam, S. S., Jani, M. F. M. \& Omar, N. A. (2011). An Empirical Study of Success Factors of Women Entrepreneurs in Southern Region in Malaysia. International Journal of Economics and Finance, vol.3:2, pp.166-175. https://doi.org/10.5539/ijef.v3n2p166

Apergis, N. \& Pekka-Economou, V. (2010). Incentives and Female Entrepreneurial Activity: Evidence from Panel Firm Level Data. International Advances in Economic Research, vol.16:4, pp.371-387. https://doi.org/10.1007/s11294-010-9277-9 
Bardasi, E., Sabarwal, S. \& Terrell, K. (2011). How Do Female Entrepreneurs Perform? Evidence from Three Developing Regions. Small Business Economics, vol.37:4, pp.417-441. https://doi.org/10.1007/s11187-011-9374-z

Baron, R. A., Markman, G. D. \& Hirsa, A. (2001). Perceptions of Women and Men as Entrepreneurs: Evidence for Differential Effects of Attributional Augmenting. Journal of Applied Psychology, vol.86:5, pp.923-929. https://doi.org/10.1037/ 0021-9010.86.5.923

Bennett, R. \& Dann, S. (2000). The Changing Experience of Australian Female Entrepreneurs. Gender, Work and Organization. https://doi.org/10.1111/14680432.00095

Brush, C. G. \& Vanderwerf, P. A. (1992). A Comparison of Methods and Sources for Obtaining Estimates of New Venture Performance. Journal of Business Venturing, vol.7:2, pp.157-170, https://doi.org/10.1016/0883-9026(92)90010-O.

Chiles, T. H., Bluedorn, A. C. \& Gupta, V. K. (2007). Beyond Creative Destruction and Entrepreneurial Discovery: A Radical Austrian Approach to Entrepreneurship. Organization Studies, vol.28:4, pp.467-493. https://doi.org/10.1177/ 0170840606067996

Coetzer, J. S. A. (2016). Women Business Owners' Start-Up Motivations and Network Content. Journal of Small Business and Enterprise Development, vol.23:2, pp.590-610. https://doi.org/http://dx.doi.org/10.1108/MRR-09-2015-0216.

Cooper, A.C. \& Gascon, F.J.G. (1992). Entrepreneurs, Processes of Founding and NewFirm Performance. In: Sexton, D.L., Kasarda, J.D. (Eds.), The State of the Art of Entrepreneurship, pp.301-340.

Kyereboah-Coleman, A. \& Osei, K. A. (2008). Outreach and Profitability of Microfinance Institutions: The Role of Governance. Journal of Economic Studies, vol.35:3, pp.236-248.

Danis, W. M., Clercq, D. De \& Petricevic, O. (2011). Are Social Networks More Important for New Business Activity in Emerging than Developed Economies? An Empirical Extension, International Business Review, vol.20:4, pp.394-408. https://doi.org/10.1016/j.ibusrev.2010.08.005

Dees, J. . (1998). The Meaning of Social Entrepreneurship Stanford University: Draft Report for the Kauffman Centre for Entrepreneurial Leadership, 1-9. 
De Bruin, A., Brush, C. G. \& Welter, F. (2007). Advancing a Framework for Coherent Research on Women's Entrepreneurship. Entrepreneurship Theory and Practice, vol.31:3, pp.323-339.

De Vita, L., Mari, M. \& Poggesi, S. (2014). Women Entrepreneurs in and From Developing Countries: Evidences from the Literature. European Management Journal, vol.32:3, pp.451-460.

Dollar, D., Gatti, R. \& Filmer, D. (1999). Gender Inequality, Income and Growth: Are Good Times Good for Women? Gender and Development, Policy Research Report on Gender and Development, Working Paper Series, No. 1 http://siteresources.worldbank.org/INTGENDER/Resources/wp1.pdf

Drine, I. \& Grach, M. (2010). Supporting Women Entrepreneurs in Tunisia, Wider Working Paper No. 2010/100. https:/www.econstor.eu/bitstream/10419/54153/1/ 63686345X.pdf

Díaz-García, M. C. \& Jiménez-Moreno, J. (2010). Entrepreneurial Intention: The Role of Gender. International Entrepreneurship and Management Journal, vol.6:3, pp.261-283.

Ekpe, I., et al., (2010). The Effect of Microfinance Factors on Women Entrepreneurs' Performance in Nigeria: A Conceptual Framework, International Journal of Business and Social Science, vol.1:2, pp.255-263.

Ekpe, I. (2011). Women Entrepreneurs and Economic Development in Nigeria: Characteristics for Success. International Journal of Business and Social Science, vol.2:1, pp.287-291.

Emslie, C. \& Hunt, K. (2009). 'Live to Work' or 'Work to Live' A Qualitative Study of Gender and Work-Life Balance among Men and Women in Mid-Life. Gender, Work \& Organization, vol.16:1, pp.151-172.

Estrin, S. \& Mickiewicz, T. (2011). Institutions and Female Entrepreneurship. Small Bus Econ, vol.37, pp.397-415. https://doi.org/10.1007/s11187-011-9373-0.

Essers, C., Benschop, Y. \& Doorewaard, H. (2010). Female Ethnicity: Understanding Muslim Immigrant Businesswomen in the Netherlands. Gender, Work \& Organization, vol.17:3, pp.320-339. 
Grine, F., Fares, D. \& Meguellati, A. (2015). Islamic Spirituality and Entrepreneurship: A Case Study of Women Entrepreneurs in Malaysia. The Journal of Happiness \& Well-Being, vol.3:1, pp.41-56.

Gupta, V. K., Turban, D. B., Wasti, S. A. \& Sikdar, A. (2009). The Role of Gender Stereotypes in Perceptions of Entrepreneurs and Intentions to Become an Entrepreneur. Entrepreneurship Theory and Practice, vol.33:2, pp.397-417.

Heilman, M. E. \& Chen, J. J. (2003). Entrepreneurship as a Solution: The Allure of SelfEmployment for Women and Minorities. Human Resource Management Review, vol.13:2, 347-364. https://doi.org/10.1016/S1053-4822(03)00021-4

Hossain, A., Naser, K., Zaman, A. \& Nuseibeh, R. (2009). Factors Influencing Women Business Development in the Developing Countries: Evidence from Bangladesh. International Journal of Organizational Analysis, vol.17:3, pp.202-224. https://doi.org/10.1108/19348830910974923

Hughes, K. D., Jennings, J. E., Brush, C., Carter, S. \& Welter, F. (2012). Extending Women's Entrepreneurship Research in New Directions. Entrepreneurship Theory and Practice, vol.36:3, pp.429-442. https://doi.org/10.1111/j.15406520.2012.00504.x

Ibeh, E. (2009). Factors Affecting Performance of Women Entrepreneurs. Journal of Women's Entrepreneurship and Education, No.1-2, pp.39-50.

Itani, H., Sidani, Y. M. \& Baalbaki, I. (2011). United Arab Emirates Female Entrepreneurs: Motivations and Frustrations. Equality, Diversity and Inclusion, vol.30:5, pp.409-424. https://doi.org/10.1108/02610151111150654

Jones, M. V., Coviello, N. \& Tang, Y. K. (2011). International Entrepreneurship Research (1989-2009): A Domain Ontology and Thematic Analysis. Journal of Business Venturing, vol.26:6, pp.632-659. https://doi.org/10.1016/j.jbusvent.2011.04.001.

Kirkwood, J. (2009). Is a Lack of Self-Confidence Hindering Women Entrepreneurs? International Journal of Gender and Entrepreneurship, vol.1:2, pp.118-133. https://doi.org/10.1108/17566260910969670

Knorr, H., Garzón, D. \& Martínez, D. (2011). Motivations and Differences Upon Reconciling Professional and Personal Life: An Empirical Study of Businesswomen and Businessmen in the Valencian Community. International Entrepreneurship and Management Journal, vol.7:3, pp.391-412. https://doi.org/10.1007/s11365-011-0202-3 
Kobeissi, N. (2010). Gender Factors and Female Entrepreneurship: International Evidence and Policy Implications, Journal of International Entrepreneurship, pp.1-35. https://doi.org/10.1007/s10843-010-0045-y

Lewis, P. (2013). The Search for an Authentic Entrepreneurial Identity: Difference and Professionalism among Women Business Owners. Gender, Work and Organization, vol.20:3, pp.252-266. https://doi.org/10.1111/j.1468-0432.2011.00568.x

M. Carter, N., \& R. Allen, K. (1997). Size Determinants of Women-Owned Businesses: Choice or Barriers to Resources? Entrepreneurship and Regional Development, vol.9:3, pp.211-220. https://doi.org/10.1080/08985629700000012

Mahmood, S., Hussain, J. \& Matlay, H. Z. (2014). Optimal Microfinance Loan Size and Poverty Reduction amongst Female Entrepreneurs in Pakistan. Journal of Small Business and Enterprise Development, vol.21:2, pp.231-249. https://doi.org/ 10.1108/JSBED-03-2014-0043

Mansell, R. (2014). Power and Interests in ICTs and Development: Exogenous and Endogenous Discourses in Contention. Journal of International Development, vol.26, pp.109-127. https://onlinelibrary.wiley.com/doi/epdf/10.1002/jid.1805

Mathew, R. V. \& Panchanatham, N. (2016). An Exploratory Study on the Development of Women Entrepreneurs: Indian Cases. Journal of Research in Marketing and Entrepreneurship, vol.18:2, pp.232-247. https://doi.org/10.1108/JRME-04-2015-0024

Mcgowan, P., Cooper, S., Durkin, M. \& O'Kane, C. (2015). The Influence of Social and Human Capital in Developing Young Women as Entrepreneurial Business Leaders. Journal of Small Business Management, vol.53:3, pp.645-661. https://doi.org/10.1111/jsbm.12176

McGregor, J. \& Tweed, D. (2002). Profiling a New Generation of Female Small Business Owners in New Zealand: Networking, Mentoring and Growth. Gender, Work and Organization, vol.9:4, pp.420-438. https://doi.org/10.1111/1468-0432.00167

Mirchandani, K. (1999). Feminist Insight on Gendered Work: New Directions in Research on Women and Entrepreneurship. Gender, Work and Organization, vol.6:4, pp.224-235. https://doi.org/10.1111/1468-0432.00085

Mwobobia, F. M. (2012). The Challenges Facing Small-Scale Women Entrepreneurs: A Case of Kenya. International Journal of Business Administration, vol.3:2, pp.112-121. https://doi.org/10.5430/ijba.v3n2p112 
Nicolaou, N., Shane, S., Cherkas, L. \& Spector, T. D. (2009). Opportunity Recognition and the Tendency to be An Entrepreneur: A Bivariate Genetics Perspective. Organizational Behavior and Human Decision Processes, vol.110:2, pp.108-117. https://doi.org/10.1016/j.obhdp.2009.08.005

Nordenmark, M., Vinberg, S. \& Strandh, M. (2012). Job Control and Demands, WorkLife Balance and Wellbeing among Self-Employed Men and Women in Europe. Vulnerable Groups \& Inclusion, vol.3:1, p.18896. https://doi.org/10.3402/ vgi.v3i0.18896

Orser, B. J., Riding, A. L. \& Manley, K. (2006). Women Entrepreneurs and Financial Capital. Entrepreneurship: Theory and Practice, vol.30:5, pp.643-665. https://doi.org/10.1111/j.1540-6520.2006.00140.x

Parvin, L., Jinrong, J. \& Rahman, M. W. (2012). Women Entrepreneurship Development in Bangladesh: What are the Challenges Ahead?, vol.6:11, pp.3862-3871. https://doi.org/10.5897/AJBM11.2858

Peters, G. (2014). Women in Business. Business Strategy Review, vol.25:3, p.43 https://doi.org/10.1111/j.1467-8616.2014.01092.x

Piacentini, M. (2013). Women Entrepreneurs in the OECD: Key Evidence and Policy Challenges, OECD Social, Employment and Migration Working Papers, No. 147, OECD Publishing, Paris. http://dx.doi.org/10.1787/5k43bvtkmb8v-en.

Popay, J., Roberts, H., Sowden, A., Petticrew, M., Arai, L., Rodgers, M., Duffy, S. (2014). Guidance on the Conduct of Narrative Synthesis in Systematic Reviews : A Product from the ESRC Methods Programme Guidance on the Conduct of Narrative Synthesis in Systematic Reviews A Product from the ESRC Methods Programme with, (May). https://doi.org/10.13140/2.1.1018.4643.

Ramadani, V. (2015). The Woman Entrepreneur in Albania: An Exploratory Study on Motivation, Problems and Success Factors, Journal of Balkan and Near Eastern Studies, vol.17:2, pp.204-221.

Raman, K., Anantharaman, R. N. \& Ramanathan, S. (2013). Environmental, Personality and Motivational Factors: A Comparison Study between Women Entrepreneurs and Women Non Entrepreneurs in Malaysia. International Journal of Business and Management, vol.8:13, pp.15-23. https://doi.org/10.5539/ijbm.v8n13p15 
Rehman, S. \& Roomi, M.A. (2012). Gender and Work-Life Balance: A Phenomenological Study of Women Entrepreneurs in Pakistan, Journal of Small Business and Enterprise Development, vol.19:2, pp.209-228. https://doi.org/10.1108/14626001211223865

Salmenniemi, S., Karhunen, P. \& Kosonen, R. (2011). Between Business and Byt: Experiences of Women Entrepreneurs in Contemporary Russia. Europe - Asia Studies, vol.63:1, pp.77-98. https://doi.org/10.1080/09668136.2011.534304

Sarfaraz, L., Faghih, N. \& Majd, A. A. (2014). The Relationship between Women Entrepreneurship and Gender Equality. Journal of Global Entrepreneurship Research, vol.4:6. https://journal-jger.springeropen.com/track/pdf/10.1186/22517316-2-6

Alam, S. S., Senik, Z. C. \& Jani, F. M. (2012). An Exploratory Study of Women Entrepreneurs in Malaysia: Motivation and Problems, Journal of Management Research, vol.4:4, pp.282-297. https://doi.org/10.5296/jmr.v4i4.2377

Sharma, M. Y. (2013). Women Entrepreneur in India, Journal of Business and Management, vol.15:3, pp.9-14. https://pdfs.semanticscholar.org/a839/ 9756d4faf59373852a9b905b1159947a93e3.pdf

Shinnar, R. S., Giacomin, O. \& Janssen, F. (2012). Entrepreneurial Perceptions and Intentions: The Role of Gender and Culture. Entrepreneurship: Theory and Practice, vol.36:3, pp.465-493. https://doi.org/10.1111/j.1540-6520.2012.00509.x.

Stephen, C. \& Wilton, W. (2006). Don't Blame the Entrepreneur, Blame the Government: The Centrality of the Government in Enterprise Development. Journal of Enterprising Culture, vol.14:1, pp.65-84.

Singh, V., Vinnicombe, S. \& James, K. (2006). Constructing a Professional Identity: How Young Female Managers Use Role Models. Women in Management Review, vol.21:1, pp.67-81. https://doi.org/10.1108/09649420610643420.

Thorpe, R., Holt, R., Macpherson, A. \& Pittaway, L. (2005). Using Knowledge within Small and Medium-Sized Firms: A Systematic Review of the Evidence. International Journal of Management Reviews, vol.7:4, pp.257-281. https://doi.org/10.1111/j.1468-2370.2005.00116.x

Tsyganova, T., \& Shirokova, G. (2010). Gender Differences in Entrepreneurship: Evidence from GEM Data, Organizations and Markets in Emerging Economies, vol.1:1, pp.120-141. 
Welsh, D. H. B., Memili, E., Kaciak, E., \& Ochi, M. (2014). Japanese Women Entrepreneurs: Implications for Family Firms, Journal of Small Business Management, vol.52:2, pp.286-305. https://doi.org/10.1111/jsbm.12099.

Vinogradov, E. \& Kolvereid, L. (2010). Home Country National Intelligence and SelfEmployment Rates among Immigrants in Norway. Intelligence, vol.38:1, pp.151-159.

William, S. \& Thawatchai, J. (2008). Impact of the Lack of Institutional Development on the Venture Capital Industry in Thailand. Journal of Enterprising Culture, vol.16:2, pp.189-204.

Wijdicks, E. F. M., Bamlet, W. R., Maramattom, B. V., Manno, E. M. \& McClelland, R. L. (2005). Validation of a New Coma Scale: The Four Score. Annals of Neurology, vol.58:4, pp.585-593. https://doi.org/10.1002/ana.20611

Dr. Saima Tabassum Siddiqui is Chairperson and Associate Professor in the Department of Business Administration, Sindh Madressatul Islam University, Karachi.

Asif Hussain Samo is Lecturer in the Department of Business Administration, Sindh Madressatul Islam University, Karachi.

Kainat Meraj is Student in the Department of Business Administration, Sindh Madressatul Islam University, Karachi. 